\title{
Тенденції розвитку лідерства в скандинавських країнах: досвід для України
}

\section{Роман Сторожев, Національна академія державного управління при Президентові України}

На сучасному етапі інтеграції Української держави до європейської спільноти перед вітчизняними лідерами постають нові завдання, які вимагають підвищення ефективності публічного управління та публічного адміністрування на засадах демократизму, людиноцентризму.

Актуальність теми розвитку публічного лідерства в Україні тісно пов'язана з вивченням досвіду зарубіжних країн щодо механізмів формування та розвитку публічного лідерства, що характеризується високим рівнем моральних цінностей, відповідальністю, комунікативністю, скромністю. Нова управлінська парадигма, яка впроваджується в публічне управління та публічне адміністрування України також вимагає впровадження нових якостей публічного лідерства, які проявляються через утвердження моральних цінностей в особистості лідера, його моделей поведінки в реформуванні публічної служби. На думку автора, такі якості лідерства як делегування повноважень у органах публічної влади, міжгалузеве співробітництво в публічному управлінні зумовлюють розвиток лідерства у контексті освітніх тенденцій зарубіжних країн.

Автор вважає, що сьогодні важливим аспектом у розвитку публічного лідерства є мобілізаційний аспект зусиль усіх керівників і підлеглих публічної влади та лідерів інститутів громадянського суспільства для подолання кризових явищ та проведення складних реформ в публічному управлінні. До таких кризових явищ належить забезпечення стабільності в умовах всесвітньої боротьби 3 пандемією GOVID-19. Однак проблема розвитку публічного лідерства у цьому аспекті не знайшла належного відображення у сучасних наукових джерелах.

У статті розкрито пріоритетні моделі публічного лідерства західноєвропейських країн як передумову формування успішної особистості, успішних лідерських якостей, тенденцією якого $є$ такий важливий чинник як публічність, оскільки до 90-х років XX ст. далеко не всі державні управлінці європейських країн були публічними.

Ключові слова: моделі лідерства, лідерські якості, особистість лідера, типологія лідерства, сучасний етап інтеграції української держави в європейське співтовариство, моральні иінності, відповідальність, комунікативність, скромність, публічність, європейські краӥни, інститути громадянського суспільства, розвиток публічного лідерства

\section{Leadership development trends in the scandinavian countries: experience for Ukraine}

\section{Roman Storozhev, National Academy for Public Administration under the President of Ukraine}

At the current stage of Ukrainian state integration into European community, country leaders face new challenges that require improving efficiency of public management and public administration based on democracy and human-centeredness. Urgency of public leadership development in Ukraine is closely related to the foreign countries' experience study on the mechanisms of formation and development of public leadership, characterized by a high level of moral values, responsibility, communication, modesty. The new management paradigm, being introduced in public administration and public management in Ukraine, also requires introduction of new qualities in public leadership, manifested through establishment of moral values in the leader's personality, leader's behavior in public service reform. According to the author, such qualities of leadership as delegation of powers in public authorities, intersectoral cooperation in public administration determine development of leadership in the context of educational trends in foreign countries. 
The author believes that today an important aspect in the development of public leadership is the mobilization aspect of the efforts of all leaders and subordinates of public authorities and leaders of civil society institutions to overcome crises and do complex reforms in public administration. Such crises include ensuring stability in global fight against the GOVID-19 pandemic. However, problem of public leadership development in this aspect has not been properly reflected in modern scientific sources.

The article reveals priority models of public leadership of Western European countries as a prerequisite for formation of successful personality, successful leadership qualities, the trend of which is such an important factor as publicity, because before the 90 s of the twentieth century not all government officials in European countries were public.

Keywords: leadership models, leadership qualities, personality of the leader, typology ofleadership, current stage of Ukrainian state integration into European community, moral values, responsibility, communication, modesty, publicity, European countries, civil society institutions, development of public leadership

\section{Тенденции развития лидерства в скандинавских странах: опыт для Украины}

\section{Роман Сторожев, Национальная академия государственного управления при Президенте Украины}

На современном этапе интеграции Украинского государства в европейское сообщество перед отечественными лидерами возникают новые задачи, которые требуют повышения эффективности публичного управления и публичного администрирования на принципах демократизма, человекоцентризма.

Актуальность темы развития общественного лидерства в Украине тесно связана с изучением опыта зарубежных стран по механизмам формирования и развития общественного лидерства, характеризуется высоким уровнем нравственных ценностей, ответственностью, коммуникативностью, скромностью. Новая управленческая парадигма, которая внедряется в общественное управление и публичное администрирование Украины также требует внедрения новых качеств публичного лидерства, которые проявляются через утверждение нравственных ценностей в личности лидера, его моделей поведения в реформировании публичной службы. По мнению автора, такие качества лидерства как делегирование полномочий в органах публичной власти, межотраслевое сотрудничество в публичном управлении обусловливают развитие лидерства в контексте образовательных тенденций зарубежных стран.

Автор считает, что сегодня важным аспектом в развитии общественного лидерства является мобилизационный аспект усилий всех руководителей и подчиненных публичной власти и лидеров институтов гражданского общества для преодоления кризисных явлений и проведения сложных реформ в публичном управлении. К таким кризисных явлений относится обеспечение стабильности в условиях всемирной борьбы с пандемией GOVID-19. Однако проблема развития общественного лидерства в этом аспекте не нашла должного отражения в современных научных источниках.

В статье раскрыто приоритетные модели публичного лидерства западноевропейских стран как предпосылку формирования успешной личности, успешных лидерских качеств, тенденцией которого является такой важный фактор как публичность, поскольку до 90-х годов. далеко не все государственные управленцы европейских стран были публичными.

Ключевье слова: модели лидерства, лидерские качества, личность лидера, типология лидерства, современный этап интеграчии украинского государства в европейское сообщество, моральные иенности, ответственность, коммуникабельность, скромность, публичность, европейские страны, институты гражданского общества, развитие общественного лидерства 


\section{Постановка проблеми.}

прямованість до транспарентності лідерства в західноєвропейських країнах стала частиною великої зміни щодо ролі чиновників найвищих рангів, оскільки саме від них почали очікувати демонстрацію публічного лідерства (Chappelet, 2017). Це була одна 3 важливих тенденцій у розвитку лідерства, оскільки чиновники до 90-х років XX ст. далеко не всі були публічними.

У цій статті ми розглянемо особливості розвитку публічного лідерства у Скандинавських країнах - Швеції, Данії, Королівстві Нідерландів, Норвегії, Швейцарії. Адже нова управлінська парадигма, яка активно впроваджується у вітчизняне публічне управління, вимагає формування нових якостей у публічного лідерства, які проявляються через утвердження моральних цінностей особистості, його моделей поведінки в комунікації, самоменеджменті, стресових ситуаціях. Такі якості лідерства, як здатність до самоосвіти, делегування повноважень, транспарентне (прозорості, відкритості та активізації) та трансформаційне співробітництво зумовлюють новий стиль розвитку лідерства у західноєвропейських країнах, яке буде корисним для впровадження в Україні (Калашник, 2013).

Аналіз останніх досліджень та публікацій свідчить про те, що проблема сучасного лідерства у публічному управлінні постійно перебуває в полі зору вітчизняних та зарубіжних вчених. Так вагомий внесок у дослідження лідерства в державному (публічному) з конкретизацією принципів зробили В. Голубь, Н. Гончарук, В. Гошовська, I. Грищенко, Г. Дмитренко, Л. Карамушка, О. Крюков, Б. Кухта, Н. Нижник, Т. Новаченко, М. Пірен, Ф. Рудич, І. Сурай, Л. Пашко та ін. Однак питання дослідження пріоритетних принципів лідерства в публічно-управлінській діяльності в науці державного управління в умовах реформування державної служби не отримало належного наукового обгрунтування, чим і зумовлена актуальність теми даної розвідки.
Мета статті - розкрити сутність пріоритетних принципів лідерства в публічно-управлінській діяльності, розкривши стан дослідженості цього питання у вітчизняній та зарубіжній літературі.

Виклад основного матеріалу. На сьогодні питання лідерства, їх пріоритетних принципів та розвитку лідерського потенціалу знаходяться в центрі уваги науковців та практиків, які усвідомлюють їх важливість для здійснення ефективного реформування публічного управління та розвитку демократії.

Скандинавські країни є прикладом того, як у доволі суворих кліматичних умовах можна побудувати взірцеву соціально-політичну систему 3 високорозвиненою економікою, високим рівнем життя людей, дотриманням їх прав і свобод.

Королівство Нідерландів визначає, що одним із значущих людських чинників особистості, яка задіяна в публічному управлінні, iii адаптація до нових викликів, є iii «якість». Тому до чиновництва в цій державі постає вимога безперервного навчання, зокрема у сфері електронної демократії (Faculté de droit, des sciences criminelles et d'administration publique, 2020).

Немає сумнівів у тому, що інформаційно-комунікаційні технології, відкриваючи нові можливості, не лише для модернізації, а й для більшої прозорості у діяльності органів влади та керівництва, сприяють підвищенню демократичної участі громадян у політичному житті держави та розвитку лідерства.

У цьому контексті велика увага приділяється безперервній освіті, у якій розрізняють довгострокові програми, що спрямовані на певну кар'єру, та короткострокові тренінги для конкретного виконання завдання чи роботи. У чому спостерігається зв'язок і взаємодія між урядом, державними та приватними університетами щодо підготовки публічних службовців (Faculté de droit, des sciences criminelles et d'administration publique, 2020).

Ще одну рису політико-адміністративної системи Нідерландів, що впливає на розви- 
ток лідерства слід виокремити, охарактеризувавши їі як взаємодію між політиками та чиновниками. Так, політики, маючи досвід адміністративної роботи, по завершенню політичної кар'єри здебільшого обіймають адміністративні посади на різних рівнях. Саме такий досвід дає посадовцям можливість порозуміння, що сприяє ефективній взаємодії та утворенню лідерських команд у публічному управлінні. Вочевидь, принцип публічності відкриває особистість лідера, супроводжуючись набуттям/зміною уявлень щодо його професійності, цінностей, реалізації як управлінця тощо, що може визначати/не визначати лідера як особистість, яку слід наслідувати.

Швеція $є$ однією 3 найбільш інноваційних і відкритих до співпраці країн світу, яка репрезентує себе глобальним лідером змін iз просування та підтримання концепції сталого розвитку. Успіх реалізації цісї концепції вимагає координованих зусиль усієї системи публічного управління, відповідно якої політика розвитку країни опирається на унікальний мікс інновацій та співпраці. Так звані «policy labs» допомагають державним агенціям задовольнити потреби суспільства, успішно вносити регуляторні зміни та фасилітувати інновації, які будуть стимулювати соціальний сталий розвиток.

Основними надавачами державних послуг у Швеції $\epsilon$ місцеві муніципалітети, робота яких базується на таких принципах: демократії-вся публічна влада реалізується через людей загальним голосуванням, представницькою демократією та парламентською системою; законопослушності - публічна влада має суворо дотримуватись закону; об'єктивності - неупередженість і рівне ставлення до всіх людей; свободи - вільне формування думок і свобода висловлення; поваги - публічна влада має бути виконана через повагу до свободи та рівності кожної людини; ефективності $i$ служіння - діяльність публічного сектору має бути здійснена недорого і з максимально можливою якістю, як тільки можливо, враховуючи наявні ресурси (Page, \& Wright, 2007, с. 135).
Згідно $з$ чинним конституційним законодавством Швеції, право встановлювати систему органів публічного управління, статус державної служби, умови її проходження надано Риксдагу. Керівництво адміністративним апаратом центру та місцевого рівня здійснює уряд.

До першої групи належать «політичні чиновники», зокрема - міністри, їх заступники, керівники урядових відомств, прокурори, губернатори, начальники поліції тощо. Специфічним можна охарактеризувати те, що основний склад вищого і середнього адміністративного персоналу не залежить від політичної орієнтації уряду, а тому $є$ незмінним. Для таких службовців припустимо підвищення в посаді, однак переміщення проти їх бажання або звільнення до досягнення встановленого віку не дозволено. Муніципалітети є незалежними від центральної влади та самостійними щодо питань визначення фінансового статусу і кадрового забезпечення. Їх співробітники не належать до державних службовців, водночас такого поняття як «ранг державних службовців» не існує (Page, \& Wright, 2007, с. 135).

Від державних службовців вимагається володіння високим професіоналізмом та відповідними особистісними якостями. Підготовка державних службовців у Швеції здійснюється в університетах, їх освіта традиційно була економічною чи юридичною, що відповідає сутності англосаксонського підходу у їх навчанні. Проте, одержуючи професійну освіту, державні службовці мають сильну підготовку в сфері права, однак підвищення якості роботи, пов'язується із застосуванням міждисциплінарного підходу, що розширює їх можливості для успішної діяльності в управлінській cфepi (Page, \& Wright, 2007, c. 135).

Застосування навчальних програм у контексті міждисциплінарного підходу, дозволяє розвивати і вдосконалювати системне та критичне мислення, комунікаційні уміння, самоорганізацію, креативність, уміння працювати в команді тощо, безсумнівно сприяє розвитку лідерства. 
Звернувшись до аналізу підвищення кваліфікації посадовців у Норвегії, бачимо, що їх перепідготовка відсутня. Там дотримуються імперативу про те, що перемога у конкурсі надає всі підстави фахівцю для повноцінного виконання своїх професійних обов'язків. Водночас, система підвищення кваліфікації публічних службовців побудована переважно на самоосвіті. Це стосується процесу самостійного оволодінням знаннями і навиками в індивідуальному порядку так і під час проходження тих чи інших курсів (Meer, Kerkhoff, Osch, 2014, с. 20-23).

Отже, для того щоб зробити кар'єру, зайняти вищу посаду в Норвегії, стати керівником, підвищити своє матеріальне благополуччя, необхідно безперервно навчатися.

Публічний службовець Норвегії самостійно може звернутися до освітньої установи та пройти навчання. Такі послуги надають найчастіше Вищі народні школи, що проводять безоплатні курси з питань розвитку демократії, залученню громадян до участі у розвитку суспільства, створенню умов для саморозвитку, самореалізації, підготовки керівників-лідерів тощо.

Визначальною формою підвищення кваліфікації є самоосвіта, що розвиває лідерство, шляхом забезпечення важливих компетентностей. Під час виконання функціональних обов'язків якість їх здійснення безпосередньо залежить від здатності службовця до самоосвіти, що розглядається як стандарт публічної служби (Meer, Kerkhoff, \& Osch, 2014, с. 20-23).

Швейцарія $\epsilon$ федеративною парламентською республікою, iї публічне управління регулюються положеннями Конституції (1999р.), основними принципами якої визначено повага до федералізму та демократії (Порадник із сучасного та ефективного управління людськими ресурсами, 2013, с. 20-23).

Державне управління Швейцарії базується на таких основоположних принципах як: нейтралітет та пряма демократія. Практика показала, що передача повноважень від центру в кантони та общини підвищує ефективність державного управління в країні. Важ- ливим здобутком швейцарської демократії $\epsilon$ різноманітний інструментарій прямої демократії, який дає змогу громадянам бути активними учасниками референдумів, законодавчих ініціатив, виборів, проведенню публічних зібрань виборців тощо (Порадник із сучасного та ефективного управління людськими ресурсами, 2013, с. 20-23).

Перед державними службовцями та їх лідерами виникає потреба запровадження нових способів та методів керівництва, які дають змогу найбільш повно виконувати покладені на них завдання. Це означає необхідність безперервного навчання, яке можна здійснювати в провідних вищих навчальних закладах. Одним із таких, в системі професійного навчання державних службовців та їх лідерів, $є$ Інститут підвищення кваліфікації в галузі державного управління (Institute for Advanced Studies in Public Administration - IDHEAP) (Порадник із сучасного та ефективного управління людськими ресурсами, 2013, с. 20-23).

У цьому інституті проходять підвищення кваліфікації представники органів влади, їх керівництво та особи, які планують після закінчення навчання працювати у публічному секторі. Навчальні програми IDHEAP затверджені на рівні конфедерації, а диплом магістра $з$ публічного управління отримав акредитацію Європейської асоціації 3 акредитації з публічного адміністрування. Навчальна підготовка слухачів в IDHEAP здійснюється в межах основних програм: магістратура $з$ публічного управління, а також публічного менеджменту та політики, докторантура $з$ публічного управління (Порадник із сучасного та ефективного управління людськими ресурсами, 2013, с. 20-23).

Разом із викладацькою діяльністю IDHEAP проводить дослідження та консультації з питань державного управління, професійні тренінги для членів адміністративних органів, що спрямовані на розвиток лідерства.

Особливістю Швейцарії є велика увага до рекрутингу майбутніх державних службовців. Відбір кандидатів у системі державного управління відбувається за умов відкритого 
конкурсу та співбесід з потенційним прямим керівництвом. Для пошуку використовуються відомі соціальні мережі Facebook, Linkedin, а також спеціалізовані портали, зокрема: Federal jobs portal: www.stelle.admin.ch/stelle/ fr/home.html, що спеціалізуються на рекрутингу держслужбовців (Порадник із сучасного та ефективного управління людськими ресурсами, 2013, с. 20-23). Серед інших важливих вимог рекрутерів до майбутніх чиновників є наявність професійної освіти, що відповідає посаді; вищої освіти, що відповідає рівню бакалавра, магістра чи доктора.

До необхідних вимог також належать знання національних мов, кожен співробітник муніципалітету має володіти не менше ніж двома мовами (71 \% німецька, $22 \%$ французька, 7 \% італійська). До уваги беруться також особисті якості та здатність і бажання безперервно навчатися та самовдосконалюватися (Van der Hoven R., 2020).

Висновок. Таким чином, проведений аналіз зарубіжного досвіду розвитку лідерства в контексті освітніх тенденцій скандинавських країн - Швеції, Норвегії, Нідерландів, Швейцарії, показує, що європейська інтеграція призвела до взаємовпливів у цьому процесі.

Визначено, що у політико-адміністративній системі Нідерландів визначальною рисою, що впливає на розвиток лідерства, $є$ взаємодія між політиками та чиновниками. Так, політики, маючи досвід адміністративної роботи, по завершенню політичної кар'єри здебільшого обійма- ють адміністративні посади на різних рівнях.

Швеція $\epsilon$ однією 3 найбільш інноваційних і відкритих до співпраці країн світу, яка репрезентує себе глобальним лідером змін із просування та підтримання концепції сталого розвитку. Успіх реалізації цієї концепції вимагає координованих зусиль усієї системи публічного управління, відповідно якої політика розвитку країни опирається на унікальний мікс інновацій та співпраці. Так звані «policy labs» допомагають державним агенціям задовольнити потреби суспільства, успішно вносити регуляторні зміни та фасилітувати інновації, які будуть стимулювати соціальний сталий розвиток.

Так для того щоб зробити кар'єру, зайняти вищу посаду в Норвегії, стати керівником, підвищити своє матеріальне благополуччя, необхідно безперервно навчатися.

Державне управління Швейцарії базується на таких основоположних принципах як: нейтралітет та пряма демократія. Практика показала, що передача повноважень від центру в кантони та общини підвищує ефективність державного управління в країні.

Окреслена одностайність обертається навколо розуміння та усвідомлення державними службовцями, управлінцями-лідерами значущості безперервного навчання, значущості рекрутингу та неприйняття до цієї когорти випадкових, непрофесійних людей. Це дає змогу ствердитися у думці про важливість актуалізації досвіду та освітніх тенденцій європейських держав та його творчої адаптації в Україні.

\section{REFERENCES}

Chappelet, J.-L. (2017). Trends in Swiss Civil Servants Training. CSPTC. Retrieved from http://www.csptc.gov. tw/_hrd/2017/images/speech3.pptx.

Council of Europe. (2013). Poradnyk iz suchasnoho ta efektyvnoho upravlinnya lyuds'kymy resursamy. Rada Yevropy [Guide to modern and effective human resource management] [in Swedish].

Działania Urzędu Służby Cywilnej mające na celu poprawę funkcjonowania administracji publicznej. Retrieved from https://www.nik.gov.pl/plik/id,1556.pdf; [in Poland].

Faculté de droit, des sciences criminelles et d'administration publique Retrieved from http://www.idheap.ch/ idheap.nsf/vwbasedocuments/idmpa01 [in French].

Gierelo, K. (2003). Wizerunek (image) - teoria i praktyka. Wrocław: Wyd. Uniwersytetu Wrocławskiego [in Poland].

Kalashnyk, N. S. (2013). Samoosvita dezhavnykh sluzhbovtsiv kompetentnisnyy pidkhid [Self-education of state employees: competence approach]. Dnipro [in Ukrainian]. 
Kempa, B. Celem KSAP jest kształcenie przyszlych liderów. Retrieved from http://www.radiomaryja.pl/informacje/ b-kempa-celem-ksap-ksztalcenie-przyszlych-liderow [in Poland].

Meer, F. M. van de, Kerkhoff, A.D.N., Osch, D.A.G.T. van. (2014). Educating and training civil servants in the Netherlands 1814-2014. IIAS Administrative History Conference, Corfu, April 26, 2014. (pp. 20-25). Corfu, Greece: IIAS Administrative History study group.

Nowoczesne przywództwo w organizacji publicznej na rzecz zmian - rola wyższych stanowisk w służbie cywilnej. Retrieved from https:// www.dsc.kprm.gov.pl/sites/default/files/skrypt-_gamma.pdf [in Poland].

Oferta szkoleń 2018. Retrieved from http:/ksap.gov.pl/ksap/sites/default /files/files/ oferta_szkolen_2018_0.pdf [in Poland].

Plan szkoleń centralnych w służbie cywilnej na $2011 \mathrm{r}$. Retrieved from https://dsc.kprm.gov.pl/sites/default/files/ plan_szkolen_centralnych_w_sluzbie_cywilnej_na_2011_r.pdf [in Poland].

Plan szkoleń centralnych w służbie cywilnej na $2018 \mathrm{r}$. Retrieved from https://dsc.kprm.gov.pl/sites/default/files/ plan_szkolen_centralnych_w_sluzbie_centralnych_na_2018_rok.pdf [in Poland].

Polityka szkoleniowa w służbie cywilnej. Retrieved from https://dsc.kprm.gov.pl/sites/ default/files/pliki/zal. nr_2.pdf [in Poland].

Rozporządzenie Prezesa Rady Ministrów z dnia 24 czerwca 2015 r. w sprawie szczegółowych warunków organizowania i prowadzenia szkoleń w służbie cywilnej. Retrieved from http://prawo.sejm.gov.pl/isap.nsf/download. xsp.pdf [in Poland].

Rozporządzenie Prezesa Rady Ministrów z dnia 24 czerwca 2015 r. w sprawie szczegółowych warunków organizowania i prowadzenia szkoleń w służbie cywilnej. Retrieved from http://prawo.sejm.gov.pl/isap.nsf/download. xsp/WDU20150000960/O/D2015096|.pdf [in Poland].

Swedish Council for Strategic Human Resources Development. An Introduction to Shared Values for Civil Servants. Retrieved from https://www.his.se/PageFiles/3429/Shared\%20Values\%20for\%20Civil\%20Servants.pdf [in Swedish].

Tomaszwska, A., \& Szymański, R. (2014). Szkolenia centralne w 2014 r. Przeglad Stużby Cywilnej, 4(31) lipiecsierpień, 14 [in Poland].

Ustawa z dnia 18 grudnia 1998 r. o służbie cywilnej. Retrieved from http://prawo.sejm.gov.pl/isap.nsf/DocDetails. xsp?id=WDU19990490483 [in Poland].

Ustawa z dnia 21 listopada 2008 r. o służbie cywilnej. Retrieved from http://prawo.sejm.gov.pl/isap.nsf/download. xsp/WDU20170001889/U/D20171889Lj.pdf [in Poland].

Ustawa z dnia 24 sierpnia 2006 r. o służbie cywilnej. Retrieved from http://prawo.sejm.gov.pl/isap.nsf/DocDetails. xsp?id=WDU20061701218; (дата звернення 03.06.2020) [in Poland].

Ustawa z dnia 5 lipca 1996 r. o służbie cywilnej. Retrieved from http://prawo.sejm.gov.pl/isap.nsf/DocDetails. xsp?id=WDU19960890402 [in Poland].

Van der Hoven R. La formation europeenne destine aux hauts fonctionnaires des Etats mwmbers de I'Union europeenne Rutger van der Hoven. Retrieved from http: //www.eipa.eu /en/eipascode/downloadarticle/\&tid=1633 [in Poland].

Wytyczne dotyczące wdrażania Polityki szkoleniowej w służbie cywilnej. Retrieved from https://dsc.kprm.gov.pl/ sites/default/files/pliki/zal._nr_3.pdf [in Poland].

\section{Сторожев Роман}

Кандидат наук 3 державного управління, доцент Національна академія державного управління при Президентові України

Email: ris03021976@ukr.net

\section{Storozhev Roman}

Ph.D. of Public Administration, Assoc. Prof.

National Academy for Public Administration under the President of Ukraine

ORCID: 0000-0001-5103-7274

Цитування: Сторожев, Р. (2020). Тенденції розвитку лідерства в скандинавських країнах: досвід для України. Аспекти публічного управління, 8(5), 90-96. doi: 1015421/152097

Citation: Storozhev, R. (2020). Tendentsii rozvytku liderstva v skandynavskykh krainakh: dosvid dlia Ukrainy [Leadership development trends in the scandinavian countries: experience for Ukraine]. Public administration aspects, 8 (5), 90-96. doi: $1015421 / 152097$ 